\title{
Několik poznámek k mediálnímu obrazu covidu-19 a jeho souvislosti s přírodovědným vzděláváním
}

\author{
Vojtěch Žák
}

Univerzita Karlova, Matematicko-fyzikální fakulta, Katedra didaktiky fyziky

Následující text je krátkým zamyšlením nad situací na jaře 2020, která vznikla v souvislosti s covidem-19. Poznámky se týkají souvislostí nastalé situace s přírodovědným a speciálně fyzikálním vzděláváním. Text se snaží reflektovat zejména mediální dění týkající se covidu v širším kontextu, jehož uvědomění může čtenáře vést $\mathrm{k}$ optimističtějšímu náhledu a konstruktivnějšímu posouzení nastalé a probíhající (ne)výjimečnosti.

\section{Ohlédnutí první: nad emaily kolegů}

Studenti mají na Moodle, který jsme používali i před tím, podrobné pokyny, co a kde si pročíst, nastudovat, označuji to dle úrovně - na nezbytné minimum, optimum a nadstandard (druhák má hodně širokou škálu od hodně slabých po velmi dobré, kterým chci poskytnout i něco navíc) - kombinuji svoje skripta, učebnice, co mám elektronicky, sbírku, nahrávky přednášek...

Dneska jsme vyzkoušeli online lekci v MS Teams (sešli jsme se úplně všichni) studenti to velmi uvítali, ale nepojedeme to jako náhradu výuky, ale jako konzultace $\mathrm{k}$ samostudiu (sami si to takto určili), $\mathrm{v}$ úterý dopoledne jako konzultace pro zájemce (typicky ty slabší studenty), kteří potřebují nějak pomoci zvládnout uložené samostudium, v pátek společná lekce, kde se látka shrne, vyložím př́ípadně složitější věci, ukážu věci na apletech, zodpovím dotazy...

Studenti dostávají mailem 1krát týdně zápis z přednášek (fotky mého zápisu na tabuli - obdobně jako na běžné přednášce, ale podrobněji okomentované) a dále přibližně tři povinné úlohy a jednu až dvě navíc (všechny s uvedenými výsledky kvůli rychlejší zpětné vazbě). Studenti mi mají dát vždy do konce týdne po mailu aspoň krátkou zpětnou vazbu (čemu nerozumí, s čím chtějí pomoct, zda chtějí komunikovat i jinak než jen po mailu apod.). Vypracované úlohy mi nemusí posílat a jejich řešení mají doporučeno konzultovat také mezi sebou. 
Výše uvedené ${ }^{1}$ (a mnohé další) řádky jsme si vyměnili s kolegy z katedry nedlouho potom, co pro nás začalo dosud nežité (a většinou z nás ani nikdy nepředstavované) období naší práce - nemožnost scházet se se studentkami a studenty (budoucími učiteli a učitelkami fyziky) na obvyklých místech a v obvyklých časech, vlastně nemožnost scházet se fyzicky vůbec. Vzájemně sdílené řádky byly a jsou optimistické; odkazují k diferenciaci, zodpovědnosti, vrstevnickému učení, ale také ke snaze o kontinuitu. Dali jsme si jimi najevo, že nechystáme pouhé přežívání ve zvláštních časech a také že není třeba začínat od nuly, vlastně že žádný ostrý začátek neexistuje.

\section{Ohlédnutí druhé: strohý výčet}

Zatímco tři výše uvedené odstavce jsou autentické e-mailové zprávy (jejich části), níže uvedený heslovitý výčet nepochází ze skutečného sešitu (deníku či spíše „ročníku“) vnímavého žáka, ale je hypotetickým zápisem: 2001 - mezinárodní terorismus (11. záríí), 2008 - velká ekonomická recese, 2015 - migrační krize, 2019 - globální změna klimatu (Greta T.), 2020 - covid-19. Tento výčet má pochopitelně typické vady výčtů: je zkratkovitý, plochý až sterilní, neúplný... co povodně v Česku v roce 2002 (pouhých pět let po jiných velkých povodních $v$ roce 1997) nebo metanolová aféra v roce 2012? Události, které nepochybně hýbaly světem; pokud tedy pojmům "hýbat" a „svět" přisoudíme vhodný význam. Ještě jednu nectnost uvedené události (nebo jak jinak je nazvat) mají - nejsou spojeny sériově, řekl by fyzik s trochou nadsázky, ale výstižně. Mezinárodní terorismus zřejmě nebyl zlikvidován velkou ekonomickou recesí a globální změna klimatu se necítí být ohrožena covidem. V mediálním světě to zařídit možná jde, ve světě nemediálním (člověku by se chtělo říct „nezprostředkovaném“) ne.

\section{Ohlédnutí třetí: nezajímavost stavu, přitažlivost změny}

Mediální prezentace zejména počtu lidí nakažených covidem během jara letošního roku nám mohly připomenout, že větší pozornost často dopřáváme sledování změny stavu než stavu samotnému. Spíše tak byly sledovány přírůstky počtů, méně pak celkové počty (ukotvené do určitého porovnání).

1 Jedná se o části emailů týkající se výuky dr. Zdeňky Koupilové, dr. Petra Kácovského a autora tohoto textu. 
Tento přístup není překvapivý; sledování změny může vést ke kvalifikovanému odhadu, co se bude dít v budoucnu, tedy umožňuje udělat si obrázek o tom, jaký nový stav jednou nastane (jaký bude např. celkový počet nakažených). Sledování změn spíše než samotného stavu, ve kterém se systém nalézá, je typický také pro př́rodovědné bádání. Konkrétní doklad toho nalezneme např. ve fyzice, kdy při řešení mnoha problémů je důležitější zabývat se nikoli polohou, ve které se těleso (soustava) nalézá, ale změnou této polohy $\mathrm{v}$ čase (tedy v podstatě rychlostí, kterou se těleso pohybuje). Dokonce ještě větší pozornosti se zpravidla těší zkoumání změny této změny polohy (jde tedy nakonec o časovou změnu rychlosti neboli o zrychlení). Zkoumá se tak dynamika systému.

Zdá se ale, že pouhé změny v čase nestačí k tomu, aby byl časový vývoj daného fenoménu, např. četnost jeho výskytu, medializován. Můžeme uvést dva smutné př́pady - vraždy a sebevraždy. Některá média poměrně hojně komunikují jejich jednotlivé případy, včetně jednotlivostí těchto jednotlivých případů, ale např. informace, že počet vražd v České republice za posledních 25 let klesl přibližně na polovinu, na méně než 150 ročně (ČSÚ, 2020a), je bohužel zřejmě nezajímavá. Obdobně počet sebevražd je téměř poloviční, v tomto případě oproti druhé polovině 60. let (ČSÚ, 2020b); ovšem zhruba 10násobný ve srovnání s počtem vražd. Není těžké dohledat a dopočítat, že počet zemřelých v souvislosti s onemocněním covid-19 během dubna a května letošního roku v České republice není o mnoho vyšší než počet sebevražd v průměrném dvouměsíčním období (na základě počtů zjištěných v předchozích letech).

Výše uvedené př́klady a porovnání nemají sloužit k lacinému až cynickému mávnutí rukou. Mají poukázat na to, že na základě veřejně dostupných dat (byt' ne často medializovaných) mohou žáci, např. už na druhém stupni základní školy, provést určitá porovnání, nad kterými se mohou zamyslet. Fakt, že žijeme ve světě s mnoha riziky, pak nemusí vyvolávat zbytečné sklíčení, protože je možné ukázat, že některá rizika jsou srovnatelně malá.

\section{Ohlédnutí čtvrté: slova, čísla, grafy a zase slova}

Nárůst počtu nakažených $v$ Česku zrychlil nebo denní nárůst nakažených $v$ Česku se opět zvýšil - tyto a další slovní obraty (samy hodny analýzy jejich smyslu) a ve zvýšené míře také spousta čísel (počtů) a grafů plnily prostor mimo nás i v nás, to podle toho, kolik se kam vešlo, ale také v závislosti na 
tom, kolik jsme dovolili, aby se kam vešlo. Velká medializace údajů o vývoji počtu nakažených, vyléčených a bohužel také zemřelých s sebou přinesla bohatý grafický materiál. Mám tím na mysli zejména různé typy grafů. Kromě téměř povinného „plynutí času“ na vodorovné ose zleva doprava a počtu lidí (případů) na svislé ose (obojí v lineárním, tedy rovnoměrném měřítku) jsme se dočkali také grafů v mediální krajině dosud téměř nespatřených, kde na svislé ose jsou počty lidí uvedeny v (dekadickém) logaritmickém měřítku, tedy jsou na ní ve stejných vzdálenostech postupně počty 10,100,1000 a tak dále. Vhodný (byt' předem nevyžádaný) materiál k diskuzi toho, že jedna a ta samá skutečnost (konkrétní vývoj počtu nakažených v čase) vypadá v různých grafech dost odlišně.

Mediální krajinou se začaly vznášet, někdy v ní i usedat, pojmy, jejichž význam by přející (přírodo)vědec rád poodkryl všem dalším lidem: model, predikce, spolehlivost dat, statistické šetření, odhad, metodika, komparace... Možná nebude nakonec stát tolik úsilí, aby se tyto a další výrazy (aspoň částečné zvnitřnění jejich významu) staly součástí kapesního průvodce inteligentního člověka po vlastním osudu (výstižnější slova než drobné zobecnění názvu knihy Pavla Tigrida mě v této souvislosti nenapadla).

V jedné studii (Janoušková, Žák, \& Rusek, 2019), kterou jsme s kolegy před nedávnem publikovali, je mnoho přímých i nepřímých odkazů na tyto většině lidí vzdálené pojmy. Zatímco následující dvě součásti př́rodovědné gramotnosti, které se naše studie týkala, znalost a používání prírodovědných pojmů a znalost a používání metod př́rodních věd, se těší pozornosti mnohých učitelů, o dalších dvou součástech, reflexi vědecké práce a širším kontextu prírodovědného poznání, je přiléhavější prohlásit, že jsou ve školním vzdělávání v lepším případě mlčky opomíjeny.

Poslední dvě uvedené součásti přírodovědné gramotnosti mimo jiné zahrnují spolehlivost, objektivitu a zobecnitelnost vědecké práce (jejích výsledků), kritické zacházení s informacemi (včetně kritického zacházení s informacemi z médií), schopnost rozlišit mezi vědeckými daty a jinými informacemi (domněnkami a pseudovědeckými informacemi), využívání prrírodovědného vzdělání a výchovy v osobním i profesním životě a také kritický př́stup $k$ dopadům př́rodovědných poznatků na společnost a životní prostředí. Kdo chtěl originální materiál k reflexi výše uvedených pojmů, ten se ho na jaře tohoto roku dočkal. Kdo nechtěl, dočkal se ho taky. 


\section{Bez závěru}

Život je cesta, připomíná ve své přednášce Odvaha ke štěstí snadno dohledatelné na YouTube filozofka Anna Hogenová. Činí tak s odkazem na Heideggerovo dílo Wegmarken a také Aristotela, Lao-c' a Ježíše. Kdokoli šel kdy po cestě, mohl si všimnout, že cesty mívají rovinky i zatáčky, z některých úseků jsou krásné výhledy, někdy ale vedou nepřehledným terénem. $Z$ cesty se dá dokonce sejít, dá se ale také zastavit a ohlédnout se zpátky. Možná že i někomu, kdo bude tento text číst později než v roce jeho vzniku, bude zřejmé, čeho všeho se text může týkat.

\section{Literatura}

ČSÚ. (2020a). Počet vražd v České republice. Dostupné z https://www.czso.cz/csu/czso/grafpocet-vrazd-v-ceske-republice

ČSÚ. (2020b). Sebevraždy. Dostupné z https://www.czso.cz/csu/czso/sebevrazdy_zaj

Janoušková, S., Žák, V., \& Rusek, M. (2019). Koncept př́rodovědné gramotnosti v České republice: analýza a porovnání. Studia paedagogica, 24(3), 93-109.

\section{Autor}

doc. RNDr. Mgr. Vojtěch Žák, Ph.D., Univerzita Karlova, Matematicko-fyzikální fakulta, Katedra didaktiky fyziky, V Holešovičkách 2, 18000 Praha 8, e-mail: Vojtech.Zak@mff.cuni.cz 